\title{
Kant on Moral Satisfaction
}

\author{
Michael Walschots \\ University of St. Andrews \\ mhwalschots@gmail.com
}

\begin{abstract}
This paper gives an account of Kant's concept of self-contentment [Selbstzufriedenheit], i.e. the satisfaction involved in the performance of moral action. This concept is vulnerable to an important objection: if moral action is satisfying, it might only ever be performed for the sake of this satisfaction. I explain Kant's response to this objection and argue that it is superior to Francis Hutcheson's response to a similar objection. I conclude by showing that two other notions of moral satisfaction in Kant's moral philosophy, namely 'sweet merit' and the highest good, also avoid the objection.

Keywords: self-contentment, Garve, Hutcheson, eudaimonism, pleasure, happiness, moral motivation
\end{abstract}

\section{Introduction}

Almost since its inception, Kant's moral philosophy has been thought by many to imply that action from duty cannot be pleasing in any way. Perhaps the most well known but also the most extreme version of this kind of response is suggested by Friedrich Schiller's famous remark $^{1}$ that, on Kant's account, one can only be certain that one has acted virtuously if one does what duty commands 'with disgust' (see Schiller 1987: 299-300, translation from Timmermann 2007: 152). On this reading, acting from duty involves or even requires that one dislike performing one's duty, but similar and more moderate readings at the very least suggest that there is nothing pleasing about doing one's duty. This is an important challenge to Kant's moral 
philosophy and is one which is still very much under discussion ${ }^{2}$, for if Kant truly does suggest that acting morally is divorced from satisfaction entirely, then perhaps his is a moral theory unsuitable to human beings.

It might be due to readings like these that it is not often mentioned that Kant has a very specific concept for the particular kind of satisfaction associated with acting morally. Kant mentions such an idea in the Critique of Practical Reason in the context of making an objection to Francis Hutcheson's theory of the moral sense:

one must first value the importance of what we call duty, the authority of the moral law, and the immediate worth that compliance with it gives a person in his own eyes, in order to feel that satisfaction in consciousness of one's conformity with it and bitter remorse if one can reproach oneself with having transgressed it. Thus one cannot feel such satisfaction or mental unease prior to cognition of obligation and cannot make it the basis of the latter. $(K p V, 5: 38)^{3}$

Kant argues here that Hutcheson is wrong to claim that the satisfaction that the moral sense enables us to feel upon perceiving moral action can ground obligation because this feeling in fact already presupposes awareness of obligation. At the same time, Kant seems to acknowledge that we nonetheless $d o$ feel such satisfaction and unease when we are aware of our conformity and transgression of duty. He says this almost explicitly a few lines later when briefly discussing the process of moral education: 'I certainly do not deny that frequent practice in conformity with this determining ground [the moral law] can finally produce subjectively a feeling of contentment with oneself [Zufriedenheit mit sich selbst]' (KpV, 5:38, translation modified). What these passages suggest, then, and contrary to the supposition of Schiller and others, is that Kant believes that acting morally is connected with a feeling of 'contentment with oneself' or, as he 
most often calls it, 'self-contentment [Selbstzufriedenheit]'. Although rarely discussed in the literature, Kant has a fairly detailed understanding of this concept and the primary task of this paper is to clarify and explain its significance within his moral philosophy.

My discussion is divided into five sections. I begin in the next section (2) with a detailed explanation of the concept of self-contentment. I illustrate that Kant contrasts self-contentment with contentment with one's condition, i.e. happiness, on the one hand, and with the satisfaction only God is capable of achieving, namely bliss [Seligkeit], on the other. I then turn in section three (3) to an objection this concept invites, namely that the introduction of any sort of pleasure or satisfaction arising from moral action threatens to reduce the moral motive to self-interest. This is what I refer to as 'the charge of eudaimonism", and it was raised in Kant's time by Christian Garve. Kant was therefore familiar with the objection, and after clarifying its precise meaning I outline Kant's response to it. I argue that the concept of self-contentment is not vulnerable to the objection. In section four (4), I turn to Francis Hutcheson's attempt to deal with a similar objection (4.1). Comparing Hutcheson's solution to Kant's is instructive because it allows us to see the nuances of Kant's position. I argue (4.2) that Kant's solution to the problem is superior to Hutcheson's. In the final section (5) I briefly discuss two further concepts in Kant's moral philosophy that also capture how moral action is satisfying, namely 'sweet merit' and the highest good. I show that these concepts are each distinct from self-contentment, but that they also avoid the charge of eudaimonism in their own way. In general, my aim is to provide a relatively comprehensive account of an important, but neglected, way in which Kant thinks moral action is satisfying. My secondary aim is thereby to combat the claim that acting from duty, on Kant's view, is unpleasant and therefore unfit for human beings. 


\section{Self- Contentment}

Kant's most explicit discussion of self-contentment in his published writings can be found in the Critique of Practical Reason, where, in the Critical Resolution of the Antinomy of Practical Reason, he asks the following question:

Have we not, however, a word that does not denote enjoyment, as the word happiness does, but that nevertheless indicates a satisfaction with one's existence, an analogue of happiness that must necessarily accompany consciousness of virtue? Yes! The word is self-contentment $[$ Selbstzufriedenheit $] .(K p V, 5: 117, \text { translation modified })^{5}$

Self-contentment is described here as first and foremost a kind of 'satisfaction', the nature of which will be discussed in more detail shortly. First, what gives rise to this feeling is, as this passage indicates, 'consciousness of virtue'. Kant explains this further in the Metaphysics of Morals: 'When a thoughtful human being has overcome incentives to vice and is aware of having done his often bitter duty' the result is 'a state of contentment and peace of soul in which virtue is its own reward' $(M d S, 6: 377){ }^{6}$ There are two important features of the awareness or consciousness that gives rise to self-contentment that should be mentioned. First, these passages indicate that self-contentment arises as the result of retrospective reflection upon action already performed, or at least a willing already performed (see GMS 4:394), i.e. it results from the awareness of 'having done [gethan zu haben]' (MdS, 6:377) one's duty. ${ }^{7}$ Second, and as the passage from the Metaphysics of Morals suggests, self-contentment arises not just from being aware of having done one's duty, i.e. from an awareness of having acted merely in conformity with duty, rather it arises when one has 'overcome incentives' and has acted or willed purely from respect for the moral law. ${ }^{8}$ 
Most importantly, Kant thinks of self-contentment as a kind of 'satisfaction [Wohlgefallen]' ( $\mathrm{KpV}, 5: 117)$, but one that is distinct from the satisfaction signified by happiness. In fact, Kant distinguishes between two kinds of contentment [Zufriedenheit] in order to make this point. In the Vigilantius notes we learn that '[c]ontentment is ... of two kinds, namely (1) with oneself and (2) with one's condition [Zustand]' (27:643, translation modified). According to Vigilantius, contentment with one's condition 'is based on the feeling of pleasure and pain' and is 'contentment ... taken in a pathological sense' (27:643). Contentment with one's condition is equivalent to 'happiness [Glück]' (27:643), which is clear in the Groundwork where Kant says that 'under the name of happiness' we understand 'entire well-being and contentment with one's condition' (GMS, 4:393, see also GMS, 4:399). Distinct from contentment with one's condition is '[c]ontentment in the moral sense', which 'always has a reference to a state founded on consciousness of the law-abiding use of our freedom, and thus on the conformity of our own actions with the moral law' (27:643). On the most basic level, then, Kant thinks the satisfaction involved in self-contentment is distinct from the pathological pleasure and pain characteristic of happiness and contentment with one's condition. It is nonetheless still a kind of satisfaction, however, and as such Kant claims it is 'an analogue of happiness' ( $\mathrm{KpV}, 5: 117$ and see 18:262). What still needs clarification, however, is what is distinct about self-contentment, namely its relation to freedom and the fact that it is contentment with one's self rather than one's condition.

Why contentment in the moral sense is contentment with one's self can be gleaned from its distinction from contentment with one's condition. Kant claims, for example, that 'happiness and well-being do not stem from our self, but from the concurrence of other conditions. What comes from us is based on us, on freedom, what [is based] on the external, comes from nature 
and luck [Glück]' (28:1296). Paying attention to the etymological root of the word happiness [Glückseligkeit], Kant therefore understands happiness as something that is based on luck [Glück] or chance, i.e. as dependent upon external conditions outside of our control. We are content with our condition [Zustand], then, when we are content with the extent to which nature has provided for our well-being, something which is at least not entirely in our control. ${ }^{9}$ Selfcontentment, on the other hand, is related to what we are capable of bringing about ourselves. As Kant says in Theory and Practice: 'Happiness contains all (and also not more than) that which nature provides us; but virtue contains what no one other than the human being can give himself or take away from himself' $(T P, 8: 283)$. In this way, Kant thinks of self-contentment as related to the practice of freedom. This will be important when it comes to the nature of the satisfaction involved in self-contentment, so it deserves closer investigation.

The connection between self-contentment and freedom is explained in the Religionsphilosophie Volckman notes: 'The pleasure with one's own person is called selfcontentment [Selbstzufriedenheit]. What is characteristic of us is what freedom consists in. As a result, the pleasure with one's freedom or with the quality of one's will is self-contentment' (28:1191). In that self-contentment results from the awareness of previously willed moral action, and for Kant moral action is characteristically free action, self-contentment is something that arises from the use of our freedom. As such, and in contrast to contentment with one's condition, self-contentment is something we are capable of freely bringing about ourselves. This is why it is called self-contentment, i.e. because we are content with what we have accomplished ourselves, not with what has been provided for us by the external world.

The most important aspect of self-contentment as a kind of satisfaction is intimately connected to the fact that it is brought about by the use of our freedom. So far, we have seen that 
self-contentment is distinct from contentment with one's condition and is thus also distinct from the pathological pleasure and pain signified by happiness. However, we have also seen that selfcontentment is analogous to happiness in that it is still a feeling of satisfaction of some sort. This leads one to ask what kind of satisfaction it might be. The answer is suggested in the second Critique when Kant claims the following:

Freedom, and the consciousness of freedom as an ability to follow the moral law with an unyielding disposition, is independence from the inclinations ... and so far as I am conscious of this freedom in following my moral maxims, it is the sole source of an unchangeable contentment ... and this can be called intellectual contentment. ( $K p V$, $5: 117-8)$

Kant goes on to distinguish intellectual contentment from 'aesthetic' contentment, namely the satisfaction of the inclinations. In fact, Kant claims that contentment is not the right term to use in the case of the inclinations, because they 'change, grow with the indulgence one allows them, and always leave behind a still greater void than one had thought to fill. Hence they are always burdensome to a rational being' ( $K p V, 5: 118)$. Satisfying one's inclinations can therefore never result in 'contentment', especially an 'unchangeable contentment', because the human being 'cannot lay them aside' (ibid.); we are, after all, both rational and sensible beings. The fact that the inclinations are always burdensome is significant here, for if freedom is 'independence from the inclinations', then freedom is also freedom 'from the discontent that always accompanies them [the inclinations]' ( $K p V, 5: 119)$. In this way, Kant says that consciousness of freedom 'can produce a negative satisfaction with one's state, that is, contentment, which in its source is contentment with one's person' $(K p V, 5: 119)$. Indeed, acting morally for Kant is to act 'not only without the cooperation of sensible impulses but even with rejection of all of them' $(K p V, 5: 72)$, 
thus acting morally is what it means to act independently of the inclinations. ${ }^{10}$ The satisfaction associated with acting morally is therefore only a 'negative satisfaction' in the sense that it is a partial or temporary relief from the burden and discontent that accompanies the inclinations. Only in this way is self-contentment a kind of satisfaction, for Kant. Self-contentment is not, strictly speaking, pleasure or even enjoyment, rather it is merely the absence of discontent. Kant still considers it a kind of satisfaction, albeit a merely 'negative' one, but this is all it can ever amount to (see $M d S, 6: 391)$.

A final, but important point is that although self-contentment is the satisfaction resulting from the absence of the discontent of the inclinations, Kant points out that self-contentment is nonetheless not complete independence from the inclinations. As both sensible and rational beings, Kant believes that '[o]ne would therefore never ascribe to a creature [i.e. a human being] the highest level of self-contentment or with other words bliss [Seligkeit]' (28:1191). Bliss, for Kant, 'is the contentment that depends on no external conditions and this belongs to God alone. Man is not of this kind; he is a dependent being' (29:600). As both rational and sensible, humans can never completely remove themselves from the burden and discontent of the inclinations, even though they may partially and temporarily do so by acting independently of them, i.e. by acting morally. Only God is completely 'independent from external causes’ (28:699, see also 29:624) and thus only He is capable of achieving bliss. At the same time, because selfcontentment is at least a partial independence from the inclinations, Kant calls it 'an analogon of blessedness' (27:656). This implies that self-contentment is a kind of satisfaction that only beings who are both sensible and rational can attain: whereas happiness is simply the well-being resulting from the inclinations and is thus attainable by all sensible beings, self-contentment is the negative satisfaction associated with being partially removed from the burden of the 
inclinations that only beings who have both inclinations and the capacity for freedom can achieve. However, because we are not completely rational, we cannot achieve the complete (and permanent) independence from the inclinations attainable by God alone, namely bliss. Indeed, because God is wholly rational and is thus both completely as well as permanently independent of all inclinations, Kant observes that 'one cannot say' that 'God is happy', but only that 'he is blissfull' (28:808). Human beings, on the other hand, can be both happy and self-content, i.e. content with their condition and content with their self, in virtue of the fact that they are both sensible and rational. Self-contentment is therefore a concept that occupies a middle place between happiness, on the one hand, and bliss, on the other.

The above has been intended to be an overview of how Kant understands selfcontentment [Selbstzufriedenheit]. I have illustrated that self-contentment is Kant's concept for the negative satisfaction connected to our retrospective awareness of having willed moral action. It is self-contentment because it is dependent upon our choice to act morally and not external circumstances. It is a type of satisfaction distinct from both happiness and bliss, but is nonetheless analogous to both. In the next section I turn to an objection that this concept invites and which was put forward by Kant's contemporary Christian Garve. As we will see, Kant was aware of this objection and responded to it. I argue that certain features of Kant's conception of self-contentment, as outlined above, make it such that he avoids the objection.

\section{Garve and the Charge of Eudaimonism}

That Kant makes room in his moral theory for a kind of satisfaction associated with acting morally is certainly advantageous when it comes to dealing with responses like Schiller's. However, to assert that moral action is connected with the above kind of satisfaction might be 
just as problematic. One major objection to such an idea was advanced by an important contemporary of Kant's, namely Christian Garve (1742-98). In his Essays on Various Topics from Morality, Literature and Social Life [Versuche über verschiedene Gegenstände aus der Moral, Literatur und dem gesellschaftlichen Leben], Garve makes the general statement that, according to the principles of some philosophers, 'the virtuous individual ... ceaselessly strives to be worthy of happiness, but - insofar as he is truly virtuous - never strives to be happy' (Garve 1792: 111-112). ${ }^{11}$ It is undeniable that Garve has Kant in mind here. At the time of the publication of Garve's Essays (1792), Kant had published both the Groundwork (1785) and the Critique of Practical Reason (1788), both of which identify acting morally with striving to be worthy of happiness (see e.g. GMS, 4:393 and $K p V, 5: 110 \mathrm{ff}$.). Garve criticizes the idea that the striving to be worthy of happiness is distinct from the desire for happiness itself when he claims the following:

For my part I confess that I grasp this division of ideas very well with my head, but I do not find this division of desires and strivings in my heart; - that it is even inconceivable to me how any person can become aware that his longing to be worthy of happiness is purely separated from the longing for happiness itself - and has therefore performed his duty entirely disinterestedly. (Garve 1792: 112)

In this passage Garve claims that although we may be able to distinguish between the 'longing to be worthy of happiness' and the 'longing for happiness itself' on a purely intellectual level, it is unclear if these two motives can in reality be found separately in the human 'heart'. Garve's main point, however, is that we have no reason for thinking that these two 'longings' are not one and the same. More specifically, Garve appears to be suggesting in this passage that, contrary to what some philosophers (i.e. Kant) may claim, the striving to be worthy of happiness is just 
reducible to the desire for happiness itself - the latter being something that surely can be found in the human heart. The problem that Garve poses to Kant is therefore that the virtuous motive, which is supposed to be distinct from the motive of self-interest, might in fact be reducible to self-interest after all. It is this latter objection that Kant's notion of self-contentment invites, so we should take a closer look at how Kant understood it.

In two texts written after the publication of Garve's Essays, namely the article 'On a recently prominent tone of superiority in philosophy' (1796) and the Metaphysics of Morals (1797), Kant mentions the position of a certain 'eudaimonist' (see $T, 8: 395 \mathrm{n}$ and $M d S, 6: 377$ ) who alleges that 'the pleasure (contentment [Zufriedenheit]) that a righteous man has in view, in order to feel it one day in the consciousness of his well-conducted course of life (and thus the prospect of his future felicity), is in fact the true motive for conducting his affairs well (in accordance with the law)' ( $T, 8: 395 \mathrm{n}$, translation modified). As Kant sees it, the eudaimonist's objection is therefore the following: because the 'righteous man' experiences contentment in relation to 'his well-conducted course of life', the desire to experience this contentment and not the striving to be worthy of happiness might be the true motive of the righteous man's 'virtuous' actions. The objection, then, is one that concerns moral psychology ${ }^{12}$ : if it is the case that acting from duty is satisfying, who is to say that the motive of duty is not just the desire for happiness in disguise? This is therefore an objection made from the point of view of someone who is sceptical of the possibility of acting solely from duty. From this sceptic's point of view, the fact that acting from duty is satisfying just reveals that what we think of as the (disinterested) duty motive is in fact the desire for satisfaction in disguise. The 'eudaimonist' Kant has in mind here is without a doubt Garve ${ }^{13}$, and as is suggested by Kant's mention of 'contentment' in the above 
passage, it is the notion of self-contentment that Kant believes makes him vulnerable to Garve's objection. $^{14}$

Kant believes the objection is misguided, however, and in both the 'Tone' essay and the Metaphysics of Morals Kant responds to the eudaimonist by distinguishing between 'pathological pleasure and moral pleasure' (MdS, 6:378). According to Kant, '[p]leasure that must precede one's observance of the law in order for one to act in conformity with the law is pathological ... but pleasure that must be preceded by the law in order to be felt is in the moral order' $(M d S, 6: 378)$. On the one hand, therefore, there are pathological pleasures, the expectation of which can act as a motive to action. ${ }^{15}$ On the other hand, there is a certain kind of pleasure that only results from acting on the basis of the moral law, i.e. from duty. With this distinction in hand, Kant responds to the eudaimonist's objection by claiming that the latter's reasoning is fallacious and his objection therefore meaningless. In the 'Tone' essay, for example, Kant says the following:

since I must assume him [the righteous person] beforehand to be righteous and obedient to the law, i.e., to be one in whom the law precedes the pleasure, in order for him subsequently to feel a pleasure of the soul in the consciousness of his well-conducted course of life, it is an empty circle in the reasoning to make the pleasure, which is a consequence, into the cause of that course of life. $(T, 8: 395)$

Based on his distinction between pathological and moral pleasure, then, Kant argues it is in fact impossible for the expectation of moral pleasure to somehow be the true motive of our strivings to be worthy of happiness. This is because it is only when we are already motivated by the moral law alone and not the expectation of future pleasure that it is possible for us to experience moral pleasure in the first place. To perform virtuous actions only for the sake of the resulting pleasure 
is precisely not to have the moral motive - it is to be motivated by the desire for pleasure. Indeed, given the nature of moral pleasure, it is simply a logical mistake ${ }^{16}$ to think one can experience moral pleasure if one's reason for acting is the expectation of this pleasure.

In sum, then, Kant's response to the eudaimonist is to show that self-contentment does not threaten the reduction of the duty motive to self-interest insofar as self-contentment is a 'moral pleasure'. Indeed, Kant suggests explicitly that self-contentment is an instance of moral pleasure when he describes the latter as 'a pleasure of the soul in the consciousness of [one's] well-conducted course of life' $(T, 8: 395) \cdot{ }^{17}$ Self-contentment requires that one first act from duty alone, and not from self-interest, so that one may retrospectively be aware of having such a motive. $^{18}$

Perhaps it goes without saying that Kant is not the first to claim that there is a particular kind of satisfaction associated with acting morally, nor is he alone in answering the kind of objection posed by Garve. What I intend to do in the next section is explain how Kant's solution to the eudaimonist's objection is better than the one offered by Francis Hutcheson. Hutcheson put forward one of the most important conceptions of moral satisfaction in the eighteenth century in that it is not just an (unintended) reward for acting morally, rather it is also what grounds our judgements of moral approbation. Kant owned copies of Hutcheson's major ethical works in translation (see Warda 1922: 50), thus he would have likely been familiar with what Hutcheson has to say about moral satisfaction. The comparison with Hutcheson is also instructive for my purposes, for by placing their respective responses to the objection side by side we are better able to see some unique features of Kant's conception of self-contentment that otherwise remain obscure. 


\section{Hutcheson, Kant, and the Eudaimonist as Sceptic}

\subsection{Hutcheson's Response to the Charge}

Hutcheson's moral theory faces a problem similar to the one outlined above when one combines his conception of the moral sense with his moral psychology. In his first major philosophical work, the Inquiry Into the Original of Our Ideas of Beauty and Virtue (1725), Hutcheson states that his aim in the second Treatise dealing with virtue is to show two things:

I. "That some Actions have to Men an immediate Goodness; or, that by a superior Sense, which I call a Moral one, we perceive Pleasure in the Contemplation of such Actions in others, and are determin'd to love the Agent, (and much more do we perceive Pleasure in being conscious of having done such Actions our selves) without any View of further natural Advantage from them.”

II. ... "what excites us to these Actions which we call Virtuous, is not an Intention to obtain even this sensible Pleasure; ... but an entirely different Principle of Action from Interest or Self-Love.” (Hutcheson 2004: 88)

As Hutcheson says here, and as he goes on to explain in more detail, the moral sense is a capacity to feel pleasure when perceiving actions that have 'an immediate Goodness'. Indeed, he even goes as far as saying that the moral sense 'gives us more Pleasure and Pain than all our other Facultys' (ibid.: 162). Hutcheson identifies actions that have an immediate goodness as those that are motivated by 'benevolence', i.e. the 'disinterested' desire for the happiness of others (see ibid.: 103). In fact, this is precisely Hutcheson's second point, namely that not all actions are motivated by 'interest or Self-love', but that it is possible to be motivated by a purely disinterested desire as well, namely for the happiness of others. A problem arises here, however, 
particularly in the case of perceiving our own benevolent actions: If acting morally amounts to acting benevolently, i.e. disinterestedly desiring the happiness of others, and perceiving our own benevolent actions gives us pleasure (indeed more pleasure than all our other faculties), then there is a risk that we only ever act benevolently in order to feel the pleasure of the moral sense, i.e. the pleasure associated with perceiving our own benevolent actions. Hutcheson himself anticipates this problem when he states the following:

the principal business of the moral Philosopher is to shew, from solid Reasons, "That universal Benevolence tends to the Happiness of the Benevolent, either from the Pleasures of Reflection, Honour, natural Tendency to engage the good Offices of Men ... or from the Sanctions of divine Laws discover'd to us by the Constitution of the Universe;" ... but not to attempt proving, "That Prospects of our own Advantage of any kind can raise in us real love to others." (ibid.: 178)

In other words, what Hutcheson wants to argue is both that benevolent actions are accompanied by some pleasure, but also that benevolent actions are never performed for the sake of this pleasure. The challenge Hutcheson faces here is therefore similar to the objection Garve posed to Kant in that it concerns moral psychology: if benevolence brings us pleasure, then who is to say that it is not 'our own Advantage' that brings about 'real love to others', i.e. who is to say that benevolence is not really just self-interest in disguise. It is important for Hutcheson to clarify how this can be the case, for otherwise his claim that not all motivation is self-interested could be called into question.

According to Hutcheson's main response ${ }^{19}$ to this worry, to say that we are able to act benevolently out of self-interest implies that we are able to raise an affection or desire in ourselves at will, i.e. that we can choose to have the affection of benevolence. Hutcheson denies 
that this is possible: 'neither Benevolence nor any other Affection or Desire can be directly raised by Volition' (ibid.: 220). Hutcheson therefore disagrees with what this objection implies about our psychology. If such a view were true, it would mean that we could be bribed not only to perform good acts for other people, but to love them as well. Similarly, such a view would imply that we could be bribed to hate someone, not just to cause them ruin. Hutcheson believes, rightly I think, that this is psychologically impossible. He claims: 'A Bribe may possibly make us attempt to ruin such a Man, or some strong Motive of Advantage may excite us to oppose his Interest; but it can never make us hate him' (ibid.: 103).

Hutcheson does, however, qualify this answer to the objection in an important way: The Prospect of any Advantage to arise to us from having any Affection, may indeed turn our Attention to those Qualities in the object, which are naturally constituted the necessary Causes or Occasions of the advantageous Affection; and if we find such Qualitys in the Object, the Affection will certainly arise. Thus indirectly the Prospect of Advantage may tend to raise any Affection. (ibid.: 220)

Hutcheson therefore believes it is possible to raise benevolence in ourselves at will and out of self-interest indirectly by turning our attention to the objects that necessarily cause or occasion such affections. One such object is the benevolent actions of others, and Hutcheson claims that when we perceive such actions and then, necessarily ${ }^{20}$, morally approve of them, 'the Affection of Good-will is ordinarily subsequent to it' (2004: 219). Disinterested benevolence is thus often 'responsive benevolence' (Bishop 1996: 3), i.e. we ourselves desire to be benevolent as a response to those we perceive as acting benevolently. Indeed, this is possible in virtue of the fact that the moral sense is a 'sense': simply passively perceiving a benevolent action sets in motion an almost mechanical process, according to Hutcheson, whereby perceiving benevolence will 
cause us to be benevolent in return and both approve of such an affection in ourselves and feel the pleasure of the moral sense as a result. This makes it possible, however, to indirectly raise benevolence in ourselves: if my intention is to experience the pleasure of the moral sense, even if I cannot raise benevolence in myself directly via an act of will, I can still do so indirectly by seeking out others who are acting benevolently.

This may not strike one as a particularly satisfying response to the charge of eudaimonism. Indeed, according to the above Hutcheson seems to grant, in however a roundabout way, that we can be benevolent from self-interest. This is an unsatisfying response especially to the charge that both Kant and Hutcheson deal with, which, as mentioned above, is put forward from the point of view of a particular kind of sceptic: both Garve and Hutcheson's imagined interlocutor are psychological egoists ${ }^{21}$, and thus are sceptical of the existence of any sort of disinterested motive to begin with. Hutcheson is attempting to argue the opposite, namely that humans can act disinterestedly and not only from self-interest. However, if Hutcheson has granted that benevolence can be raised by self-interest, he risks claiming that disinterested benevolence is possible only if raised by self-interest. Although Hutcheson might argue that benevolence is not only possible in the responsive situations described above, the fact that it can be raised from self-interest at all seems to grant the psychological egoist a bit too much. A moderate egoist, for example, may be perfectly happy to grant that benevolence is possible when brought about by self-interest in the way Hutcheson allows, for they might argue that this in fact does nothing to disprove their core claim that humans are, in essence, entirely self-interested. Hutcheson's writings suggest that he would not be happy to grant the egoist this much. As a result, Hutcheson's response to the objection is not a particularly strong one. 


\subsection{Kant's Response to the Sceptical Challenge}

Kant's solution to the charge of eudaimonism is more satisfying than Hutcheson's, and this is due, above all, to an important feature of self-contentment that has not yet been discussed. At the beginning of this paper I mentioned that Kant discusses self-contentment in the second Critique in connection with an objection he makes to Hutcheson's moral sense theory, namely that the satisfaction of the moral sense cannot ground moral judgement, for the ability to experience such satisfaction in fact presupposes awareness or knowledge of moral obligation (see $K p V, 5: 38$ ). Shortly after making this objection, Kant discusses self-contentment in relation to moral education and claims:

Someone must be at least half way toward being an honest man to even frame for himself a representation of those feelings [i.e. of satisfaction and mental unease]. I certainly do not deny that frequent practice in conformity with this determining ground [the moral law] can finally produce subjectively a feeling of contentment with oneself [Zufriedenheit mit sich selbst]. (KpV, 5:38, translation modified)

To reiterate, Kant's point against moral sense theory is that the pleasure and pain experienced by the moral sense cannot ground our ideas of moral right and wrong, because the possibility of having such feelings, according to Kant, presupposes we are already aware of our moral obligations. For this reason Kant believes there is a 'deception [Täuschung]' (ibid.) going on in moral sense theory. In contrast to such a theory, Kant says that self-contentment can only be felt after one is 'at least half way' moral, which involves being on the road to becoming 'an honest person', among other things. ${ }^{22}$ In order to experience self-contentment, then, one at least needs to have had 'frequent practice' acting virtuously and thus takes place after a somewhat extended 
period of time. This means that self-contentment is not something that can be experienced every time one's motive is the moral law alone. This is where Kant and Hutcheson differ: for Kant, self-contentment is not the kind of thing one can expect to experience after the performance of any single act alone, but only after one is 'at least half way' moral.

In light of the fact that self-contentment is not something one experiences every time one acts from duty, Kant's solution to the charge of eudaimonism is different from Hutcheson's in an important way. For Hutcheson, it was the fact that certain objects necessarily raise the affection of benevolence in human beings, paired with the idea that the pleasure of the moral sense could be experienced after the performance of every benevolent action, that made it possible, on his account, for self-interest to indirectly raise benevolence. An important feature of this view is therefore that the pleasure of acting morally can be experienced no matter how far along one is in the process of moral education. Indeed, according to Hutcheson one could in principle experience the pleasure of the moral sense, i.e. his notion of moral satisfaction, if one is a vicious person; even an entirely selfish person could experience moral satisfaction, so long as they acted benevolently just once. This is precisely what Kant wishes to deny. For Kant, the satisfaction associated with virtuous action can only be experienced by one who is at least half way to acquiring a virtuous disposition, which means that it is strictly impossible, even indirectly, to bring about this satisfaction in a particular instance if one's motive is self-interest. Kant therefore entirely rules out the possibility of acting morally for the sake of self-interest. As such, Kant avoids the sceptical challenge posed by the psychological egoist, in his instance Garve, in a much more satisfactory fashion: the striving to be worthy of happiness is not the same as the striving for happiness itself, and it is strictly impossible for the moral motive to be reduced to self-interest. Kant therefore does not grant even the moderate egoist as much as Hutcheson does, 
and for this reason Kant's notion of self-contentment amounts to a more satisfying solution to the charge of eudaimonism than that offered by Hutcheson.

\section{Varieties of Moral Satisfaction}

In the above sections my focus has been on Kant's understanding of self-contentment and how it both invites and avoids the sceptical challenge posed by Garve. Even if Kant successfully avoids this challenge, however, if we return to Schiller's response then Kant may not be in any better a position than he was when we started. One might argue, for example, that selfcontentment, as a merely 'negative' satisfaction, is no real satisfaction at all, and thus the objection remains that Kant's moral theory is unfit for human beings given its complete separation from any kind of real satisfaction. Self-contentment is not the only concept Kant has for how moral action can be satisfying, however. In this last section I wish to briefly discuss two additional concepts that capture the way in which virtue is satisfying, for Kant, as well as indicate how they each avoid the charge of eudaimonism.

First, in the Metaphysics of Morals Kant acknowledges that there is something beyond self-contentment, i.e. something that is a reward for virtue but that is also more positive. As Kant says there:

there is a subjective principle of ethical reward, that is, a receptivity to being rewarded in accordance with laws of virtue: the reward, namely, of a moral pleasure that goes beyond mere contentment with oneself (which can be merely negative) and which is celebrated in the saying that, through consciousness of this pleasure, virtue is its own reward. (MdS, $6: 391)$ 
Kant goes on to explain that this reward can be called 'sweet merit' and it consists in 'a human being's merit in relation to other human beings for promoting what all human beings recognize as their natural end (for making their happiness his own)' (MdS, 6:391). Kant says that 'conscious of it [advancing the happiness of others] produces a moral enjoyment in which men are inclined by sympathy to revel' ( $M d S, 6: 391)$. In these passages Kant claims that being aware of promoting the happiness of others produces a moral enjoyment in us. The role of 'sympathy [Mitfreude]' here is decisive: our ability to sympathize with others and feel happy when they are (which happens when we make the happiness of others our end), is a 'sweet' reward that we are merited in experiencing for helping others. At the same time, Kant also discusses 'bitter merit' in this context, which he claims 'comes from promoting the true well-being of others even when they fail to recognize it as such (when they are unappreciative and ungrateful) ... All that it produces is contentment with oneself, although in this case the merit would be greater still' (MdS, 6:391). Kant thus contrasts sweet merit with self-contentment, the latter being the (sometimes bitter) merit we experience from promoting the well-being of others even when they do not appreciate our efforts. This is of a higher order than 'sweet merit', even though it is a merely negative satisfaction. The most important difference between sweet merit and selfcontentment, however, is that the negative satisfaction of self-contentment is the only kind of merit we can ever count on since, as I discussed above, it is the only kind of satisfaction that is in our control. This is the case because happiness, as Kant says in the Groundwork, 'is so indeterminate a concept that, even though every human being wishes to achieve it, yet he can never say determinately and in agreement with himself what he actually wishes and wants' (GMS, 4:418). As such, one could say that the happiness of others is even more indeterminate, thus it is even more difficult for us to reliably promote. And this is what makes it such that sweet 
merit does not even invite an objection like Garve's: we would not be motivated to pursue virtue in order to attain sweet merit, for despite our efforts we cannot reliably expect to promote the happiness of others and feel happiness through sympathy as a result, for we cannot possibly determine what the happiness of others consists in.

Kant's most well-known and perhaps most important conception of a satisfaction connected to acting morally is, of course, his notion of the highest good. As Kant says in the second Critique, the idea of the highest good connects 'morality of disposition ... as cause with happiness as effect in the sensible world' (KpV, 5:115). The many details and problems associated with Kant's notion of the highest good aside, what is relevant for the purposes of this paper is that the idea of the highest good invites the same kind of sceptical challenge discussed above. Indeed, Arthur Schopenhauer raised this kind of objection in his Critique of the Kantian Philosophy:

Happiness in the highest good is certainly not supposed to be the real motive for virtue: it stands there nonetheless, like a secret article whose presence turns the rest of the contract into a mere sham. It is not actually the reward of virtue, but rather a free gift that virtue furtively seeks out after performing its work. (Schopenhauer 2010: 555)

Kant seems to have been aware that the highest good invites the charge of eudaimonism as well, for he takes Garve's objection to be directed towards both it and self-contentment. This is evident in Kant's 'Theory and Practice' essay, where Kant names Garve explicitly as his addressee (see $T P, 8: 278$ ) and states in a footnote that the incentive which is present in the idea of the highest good possible in the world by his cooperation is not his own happiness thereby intended but only this idea as end in itself, and hence compliance with it as duty. For it contains no prospect of happiness absolutely, 
but only of a proportion between it and the worthiness of a subject, whatever that may be.

But a determination of will which limits itself and its aim of belonging to such a whole to this condition is not selfish. (TP, 8:279n)

In this passage Kant asserts explicitly that the fact that the highest good includes happiness does not mean that we pursue virtue, i.e. becoming worthy of happiness, from selfish motives. His explanation of why this is the case is interesting: happiness is not something I can trust to result necessarily or 'absolutely' from acting virtuously. As he explains most clearly in the Critique of Pure Reason, happiness is merely what I can hope to result 'if I behave so as not to be unworthy of happiness' (A 809/B 837). Given the uncertainty of happiness resulting from making oneself worthy of happiness, happiness is not much of an incentive to acting virtuously. ${ }^{23}$ Indeed, sweet merit and the highest good have this feature in common: whether they are bestowed upon us is uncertain, unreliable, and outside of our control. The only kind of moral satisfaction we can rely on is self-contentment, for it is the only kind of moral satisfaction that is fully in our control. The only reliable way of achieving self-contentment, however, it to set aside self-interest so that we might reflect on our past actions and feel justified that we have done our duty for duty's sake.

\section{Conclusion}

The goal of this paper has been, first and foremost, to give an account of a neglected conception of moral satisfaction in Kant's moral philosophy, namely self-contentment. My secondary aim has been to make a small contribution to the debate surrounding the alleged unpleasant nature of Kant's account of moral action. I hope to have made progress in showing that, rather than suggesting that the moral life is one devoid of joy or is even one necessarily bound up with feelings of 'disgust', as Schiller would have us believe, Kant's moral theory in 
fact reserves an important place for a unique feeling of moral satisfaction, and indeed one which does not threaten to reduce his position to eudaimonism. ${ }^{24}$

\section{References}

Allison, Henry. (1990) Kant's Theory of Freedom. Cambridge: Cambridge University Press.

Beck, Lewis White. (1960) A Commentary on Kant's Critique of Practical Reason. Chicago: University of Chicago Press.

Bishop, John D. (1996) 'Moral Motivation and the Development of Hutcheson's Philosophy.' Journal of the History of Ideas, 57, no. 2, 277-295.

Engstrom, Stephen. (2015) 'Ancient Insights in Kant's Conception of the Highest Good' in Lara Denis and Oliver Sensen (eds.), Kant's Lectures on Ethics: A Critical Guide (Cambridge: Cambridge University Press), pp. 103-119.

- (2007) 'Kant on the Agreeable and the Good.' In Sergio Tenenbaum (ed.), Moral Psychology (Amsterdam: Rodopi), pp. 111-160.

Forman, David. (2016) 'Kant's Moderate Cynicism and the Harmony Between Virtue and Worldly Happiness'. Journal of the History of Philosophy, 54, no.1, 75-109.

Garve, Christian. (1792) Versuche aus verschiedene Gegenstände der Moral, Literatur und dem gesellschaftichen Leben. Teil I. Breslau.

Hume, David. (1998) An Enquiry Concerning the Principles of Morals. Edited by Tom L. Beauchamp. Oxford: Clarendon Press. - (1756) Sittenlehre der Gesellschaft. Hamburg and Leipzig.

Hutcheson, Francis. (2004) An Inquiry into the Original of Our Ideas of Beauty and Virtue. Edited with Introduction by Wolfgang Leidhold. Indianpolis: Liberty Press. 
Kant, Immanuel. (1900ff.) Gesammelte Schriften (Akademie Ausgabe). Vol. 1 - 22 Edited by Preussische Akademie der Wissenschaften, Vol. 23 Edited by Deutsche Akademie der Wissenschaften zu Berlin, Vol. 24ff. Edited by Akademie der Wissenschaften zu Göttingen. Berlin.

McCarty, Richard. (2009) Kant's Theory of Action. Oxford: Oxford University Press.

Schiller, Friedrich. (1987) Werke. Vol. I. Edited by G. Fricke and H.G. Göpfert. Hanser.

Schopenhauer, Arthur. (2010) The World as Will and Representation. Volume 1. Translated and Edited by Judith Norman, Alistair Welchman, and Christopher Janaway. Cambridge: Cambridge University Press.

Timmermann, Jens. (2015) 'Divine Existence and Moral Motivation' in Joachim Aufderheide and Ralf M. Bader (eds.), The Highest Good in Aristotle and Kant (Oxford: Oxford University Press), pp. 683-692.

- (2007) Kant's Groundwork of the Metaphysics of Morals: A Commentary. Cambridge.

Warda, Arthur. (1922) Kants Bücher. Berlin: Martin Breslauer.

Ware, Owen. (2014) 'Kant on Moral Sensibility and Moral Motivation'. Journal of the History of Philosophy, 52, no.4, 727-746.

Wolff, Christian. (1733) Vernunftige Gedamnken von der Menschen Thun und Lassen zur Beförderung ihrer Glückseligkeit. $4^{\text {th }}$ Edition. Halle.

Wood, Allen. (1999) Kant's Ethical Thought. Cambridge: Cambridge University Press. - (1970) Kant's Moral Religion. Ithaca: Cornell University Press.

\footnotetext{
${ }^{1}$ Whether Schiller was attacking Kant or simply parodying Kant's critics is a matter of debate. See Timmermann (2007: 152) and Wood (1999: 28-9).

${ }^{2}$ For a recent discussion see Forman (2016).
} 
${ }^{3}$ All references to Kant's works cite the volume and page number of his Gesammelte Schriften (see Kant 1900ff.). In general, I use the translations of Kant's texts available in the Cambridge Edition of the Works of Immanuel Kant, and I indicate where these translations are modified. When referring to individual works, I make use of the following abbreviations: Anth-Anthropology from a Pragmatic Point of View, GMS - Groundwork of the Metaphysics of Morals, KpV - Critique of Practical Reason, MdS Metaphysics of Morals, Rel-Religion Within the Boundaries of Mere Reason, T- 'On a recently prominent tone of superiority in philosophy', $T P$ - 'On the Common Saying: That may be correct in theory, but it is of no use in practice'.

${ }^{4}$ In line with Engstrom (2015: 112).

${ }^{5}$ Lewis White Beck suggests that Kant might be answering David Hume in this passage, who claims the following in his An Enquiry Concerning the Principles of Morals: 'It seems indeed certain, that the sentiment of conscious worth, the self-satisfaction proceeding from a review of man's own conduct and character; it seems certain, I say, that this sentiment, which, though the most common of all others, has no proper name in our language' (Hume 1998: 103). Kant owned a copy of the first German translation of the second Enquiry (see Warda 1922: 50), a translation made on the basis of the second edition of 1753. Interestingly enough, for 'self-satisfaction' in this passage, this translation uses 'Selbstzufriedenheit' (see Hume 1756: 117). It therefore strikes me as unlikely that Kant would be answering Hume in this passage, for it would be odd for Kant to put forward a word already found in Hume's text in this context. If it is true that Kant is in dialogue with Hume here, perhaps Kant's point is merely to emphasize that there is a word for the phenomenon Hume is describing in German, namely Selbstzufriedenheit, if there is not one in English. Selbstzufriedenheit was not an uncommon term at the time, for in addition to this translation of Hume, it can be found in Christian Wolff's Deutsche Ethik as well (see Wolff 1733: 283-4).

${ }^{6}$ It deserves mention here that Kant occasionally speaks of a correlate phenomenon of 'discontentment [Unzufriedenheit]' (see e.g. TP, 8:283n) that results from the awareness of not having done one's duty. In the following, I focus exclusively on self-contentment because Kant himself discusses this positive notion 
more often, and also because it is this term that functions most prominently in the objection I discuss later in the paper. This feeling of discontentment seems closely related to what Owen Ware calls Kant's conception of the 'pain of self-conceit', and which he describes as a 'reproach for what we have already done' (Ware 2014: 738 and see ibid.:735ff). Because I limit myself to discussing only those pieces of secondary literature that are immediately relevant to my focus in this paper, I cannot discuss this or any of the many other interesting aspects of Ware's article here.

${ }^{7}$ My reading therefore agrees with Allen Wood's (see 1970: 48f.), but I disagree with both Beck, who suggests that self-contentment is equivalent to both moral feeling (see 1960: 224) as well as the positive side of respect (ibid.: 229), and Richard McCarty, who discusses moral pleasure, self-contentment, and respect as if they were the same phenomenon (see 2009: 176). I argue below that it is correct to say that self-contentment is a kind of moral pleasure, but self-contentment is equivalent to neither the positive side of respect, nor to moral feeling, primarily because these latter two concepts refer to feelings that takes place prior to the willing and therefore also the execution of action. For example, in his most extensive discussion of both respect and moral feeling in the second Critique (the third chapter of the Analytic), Kant claims that these concepts refer to feelings that are brought about in the mind when the a priori moral law becomes an incentive and determines the will on its own (see $K p V, 5: 71 \mathrm{ff}$.). The determination of the will is what must take place before any actual willing of an action, thus if respect and moral feeling are brought about at this stage, then they precede willing. As indicated in the passages just quoted, however, self-contentment arises only once willing is completed and we retrospectively reflect on the fact that we were motivated by the moral law alone. Although self-contentment is surely a feeling associated with the willing of moral action, it occurs at a different stage of this process, i.e. not prior to or even during the process of willing but subsequent to it. Additionally, both respect and moral feeling take place each time we are conscious of the moral law (see e.g. $K p V, 5: 80$ ). As I illustrate below, self-contentment can only be experienced once one makes significant progress towards becoming a virtuous person, and thus is not experienced each time the moral law determines the will. 
${ }^{8}$ An issue arises here if we consider self-contentment in light of Kant's doctrine of motivational obscurity, i.e. the idea that it is difficult if not impossible for human beings to know the true motives behind their purportedly 'moral' actions (see e.g. GMS, 4:407, Rel, 6:51, MdS, 6:392). The issue is the following: if self-contentment arises from the awareness of having willed action not only in conformity with duty but from duty, then there is a concern that we can never experience self-contentment because we can never know with certainty that we have done our duty from duty. In order to give an account of how self-contentment is possible, then, we need a way to explain how we can be aware of having done our duty. While a highly interesting topic that deserves more discussion in the literature, providing a full account of how this is possible, for Kant, would take me too far afield from the main purposes of my paper. However, I would like to take this opportunity to make a preliminary attempt at resolving the issue.

I believe the clue to resolving this issue is evident from the fact that Kant thinks we can overestimate our morality, as is apparent in his definition of arrogance (arrogantia). In the Collins lectures notes, for example, arrogance is what 'makes an unwarranted pretension to merit. It lays claim to more moral perfections than are due to it' $(27: 357)$, and in the Vigilantius notes arrogance is said to lead us to 'engender a self-contentment in ourselves, and respect ourselves self-lovingly, without assessment of our true moral worth' (27:622). Insofar as Kant believes that we can be arrogant and we can be mistaken in our assessment of the extent to which we have acted morally, he acknowledges that such an assessment is fallible and thus never certain. In contrast to the unjustified assessment of our worth involved in arrogance, Kant also mentions 'a justified satisfaction with oneself [ein gegrundetes Wohlgefallen gegen sich selbst]' (27:622, emphasis added). This presumably involves a more accurate assessment of our motives, though still not a certain knowledge thereof. Accordingly, when Kant says that self-contentment arises from our awareness of having acted from duty, I do not take him to mean that we must know our motives in order for it to arise, but rather that it arises merely from our believing ourselves to have acted from duty alone. Given this opens up the possibility of overestimating (or indeed underestimating) the extent to which we have done so, it is essential that we do our best to assess the 
morality of our previously completed actions accurately and have good reason to think we have acted not only in conformity to the law, but from the law as well (cf. $M d S, 6: 441$ ). Although we may never be certain, this is all we can hope for given the obscurity of our true motives. In any event, what is important for my discussion is that motivational obscurity does not prevent one from experiencing self-contentment, it just means experiencing this can be, as Kant says, justified or unjustified.

${ }^{9}$ Indeed, Kant even suggests that too much meddling on our part to secure our own happiness can even bring us further away from securing our own happiness (see GMS, 4:395-6).

${ }^{10}$ An important point deserves clarification here. If the exercise of freedom is accompanied by the negative satisfaction of being free from the burden and discontent of the inclinations, then one may worry that any exercise of freedom might be accompanied by such a negative satisfaction, not just the free choice of moral action. Without getting into Kant's account of free choice in detail, I wish to make it clear that self-contentment does not arise from the exercise of any free choice, but only from the performance of free moral action. This is the case, for Kant, because he believes that all action not motivated solely by the moral law involves the inclinations in some way. Kant suggests this in the Groundwork (see e.g. 4:397f.), in the second Critique (see e.g. 5:72 and 5:85), in the Metaphysics of Morals (see e.g. 6:380-1), and also in Religion within the Boundaries of Reason Alone (see e.g. 6:30). What this means is that whenever we do not act solely from duty, although we still act freely, we nonetheless choose to act on the inclinations. In this way, only acting from the moral law alone involves both acting freely and acting independently of the inclinations, which is why only moral action is accompanied by the negative satisfaction of self-contentment.

${ }^{11}$ All translations of Garve in this paper are my own.

${ }^{12}$ This point is significant, because it means that the eudaimonist's objection does not concern moral education. Whether acting in conformity with duty but from self-interested motives can eventually lead us to act from duty is a different question altogether. Kant in fact suggests that this is his view when he 
discusses 'permissible moral illusion'(see Anth, 7:151). In his Lectures on Pedagogy as well (see 9:450ff.), Kant outlines four stages of moral education, and frequent practice in conformity with the law (but from, perhaps, self-interest) takes place during the third, 'civilizing' stage. Indeed, Kant would likely want to insist that acting from self-interest can and even must be a stage of moral education, for to deny this would seem to rule out moral education altogether. At any rate, the important point is that the role Kant ascribes to self-interest in moral education is a different matter than what is at issue in relation to the eudaimonist's objection.

${ }^{13}$ After criticizing Kant in his Essays, for example, Garve asserts explicitly that 'it is permissible to speak of happiness as the only conceivable end of things' (1792: 114).

${ }^{14}$ As I discuss in the final section of this paper, it is not only the notion of self-contentment that makes Kant vulnerable to the eudaimonist's objection, but his concept of the highest good as well. This is at least how many interpreters have seen the matter, and Kant seems to have taken the charge of eudaimonism to apply to both ideas as well. As I argue over the course of this paper, Kant believed that they each avoid the challenge, albeit in different ways.

${ }^{15}$ To be clear, we do not necessarily need to experience pleasure for us to desire something, according to Kant. Kant's distinction between instinct (Instinkt) and inclination (Neigung) is meant to capture precisely this point: an inclination 'presupposes acquaintance with the object of desire' (Rel, 6:29n) whereas an instinct does not.

${ }^{16}$ In the 'Tone' essay Kant identifies the logical mistake as a 'fallacia causae non causae' $(T, 8: 395$ n), i.e. the fallacy of a cause that is not a cause. In Garve's case, then, the fallacy committed is thinking that moral pleasure can cause or bring about a desire - moral pleasure is the effect of desiring to act morally for its own sake and is simply incapable of causing us to act as pathological pleasure can.

${ }^{17}$ In this respect Stephen Engstrom is correct to suggest that self-contentment is just a different term for moral pleasure (see Engstrom 2007: 144). Strictly speaking, however, moral pleasure is a type of pleasure, and self-contentment is a particular instance of moral pleasure. It is certainly correct to say that 
self-contentment is $a$ moral pleasure in that it can only be felt after one is already 'righteous and obedient to the law' $(T, 8: 395)$. At the same time, we have to be careful here, for as I illustrated above, selfcontentment is not a pleasure if by pleasure we mean the pathological pleasure of happiness. Indeed, Kant himself seems sceptical of calling it a pleasure as well when after referring to it as such in the 'Tone' essay he immediately clarifies, in brackets, that what he means is '(contentment)' (see $T, 8: 395 \mathrm{n})$.

${ }^{18}$ For a similar but very brief reconstruction of Kant's response to this kind of challenge, see Wood (1970: 38-50).

${ }^{19}$ Hutcheson also offers the additional response, not relevant for my discussion here, that acting virtuously is sometimes accompanied by pain, as is the case when we are helping someone in distress, for example. As such, it is not clear that we would in fact want to raise benevolence in ourselves from selfinterest (see Hutcheson 2004: 220-1).

${ }^{20}$ Similar to what Kant says about our inability to withhold feeling respect for persons with merit (see $K p V, 5: 77)$, Hutcheson believes we need but 'represent a Character as generous, kind, faithful, humane, tho in the most distant Parts of the World, and we cannot avoid loving it with Esteem and Complacence' (Hutcheson 2004: 103).

${ }^{21}$ I noted above how Garve believes that happiness is the final end of all beings. Similarly, Hutcheson explicitly names Bernard Mandeville, widely regarded as the prototypical egoist, on the title page of the first edition of the Inquiry as one of his targets.

${ }^{22}$ What exactly it means to be 'at least half way toward being an honest man' is unclear. I do not wish to pursue this question at length, for it would involve an extended discussion of Kant's understanding of the process of moral education. At the same time, a promising way of explaining the idea is suggested in Religion Within the Boundaries of Mere Reason, where Kant claims that virtue is 'acquired little by little, and to some it means a long habituation (in observance of the law), in virtue of which a human being, through gradual reformation of conduct and consolidation of his maxims, passes from a propensity to vice 
to its opposite' (Rel, 6:47). Being half way towards being virtuous thus might minimally involve being more inclined to virtue than vice. Kant also explains this as being 'upon the road of endless progress toward holiness' where one has 'the firm resolve to comply with one's duty' (Rel, 6:47). In addition, Kant's discussion of moral sense theory at $K p V, 5: 38$ suggests that being half way moral involves some knowledge of our moral obligations as well.

${ }^{23}$ As Jens Timmermann explains (see 2015: 688), this is exactly why Kant argues, at the end of the Doctrine of Elements in the second Critique, that it would not be better for us to have theoretical cognition, as opposed to mere practical cognition, of the immortality of the soul and the existence of God: were we to know these things with certainty, we would know that divine reward and punishment would follow certain actions necessarily, and thus we would only ever act from self interest.

${ }^{24}$ I would like to thank the Social Science and Humanities Research Council of Canada, the German Academic Exchange Service, as well as the Interdisciplinary Centre for European Enlightenment Studies in Halle for their generous financial support that made research on this paper possible. Thanks are also due to audiences in Frankfurt, Oxford, Vienna, and Halle for their helpful feedback on earlier versions of this paper. Deserving of special mention are Corey Dyck, Lorne Falkenstein, Nora Kassan, Heiner Klemme, Dennis Klimchuk, Florian Marwede, Dmitri Pisartchik, and Jens Timmermann for their extensive feedback and encouragement. I also thank two anonymous reviewers at Kantian Review whose many comments and criticisms have greatly refined and improved the paper. 